TRANSFORMASI PEMBELAJARAN BERBASIS PROYEK SCIENCE, TECHNOLOGY, ENGINEERING AND MATHEMATICS DI MASA PANDEMI COVID-19

\author{
Beny Saputra ${ }^{1}$, Agus Sujarwanta ${ }^{2}$ \\ ${ }^{1,2}$ Universitas Muhammadiyah Metro \\ 1Email: benypedia@gmail.com, ${ }^{2}$ Email: agussujarwanta5@gmail.com
}

\begin{abstract}
Abstrak: Penelitian ini berfokus pada transformasi pembelajaran berbasis proyek (PjBL) Science, Technologi, Engineering, and Mathematics (STEM) di masa pandemi Covid-19, di mana pembelajaran di sekolah mengalami perubahan signifikan dari pembelajaran konvensional (tatap muka) menjadi pembelajaran daring, mengikuti protokol kesehatan physical distancing yang dianjurkan oleh pemerintah saat ini. Pembelajaran daring STEM-PjBL melalui platform e-learning efektif dilakukan di masa pandemic Covid-19 dengan memberikan proyek kepada peserta didik yang melibatkan sains, teknologi, teknik dan matematika. Pembelajaran STEM-PjBL meningkatkan hasil belajar, kompetensi dan motivasi belajar peserta didik, menciptakan pembelajaran yang lebih bermakna, membantu peserta didik dalam memecahkan masalah, dan mendukung karir di masa depan. Penggunaan aplikasi daring untuk pembelajaran berupa google classroom dan media sosial menjadi pilihan utama berdasarkan tingkat kemudahan penggunaan. STEM-PjBL. Pembelajaran PjBL-STEM ini juga memperlihatkan kemampuan sains peserta didik meliputi membaca, mengamati, dan memecahkan masalah dalam kehidupan sehari-hari. Peningkatan kecakapan hidup ini meliputi kecakapan personal, sosial, akademik dan vokasional. Integrasi ini lebih efektif dibandingkan dengan pembelajaran konvensional dalam meningkatkan hasil belajar berupa kemampuan berpikir kreatif dan keterampilan proses sains. Kendala dari pembelajaran daring ini meliputi layanan internet yang terbatas, serta sarana dan prasarana pengguna sebagian belum terpenuhi, misalnya smartphone dan laptop, sehingga perlu upaya lebih lanjut dan maksimal dari semua pihak.
\end{abstract}

Kata kunci: transformasi, pembelajaran berbasis proyek, STEM, Covid-19.

\begin{abstract}
This research focuses on the transformation of project-based learning (PjBL) Science, Technology, Engineering, and Mathematics (STEM) during the Covid-19 pandemic, where learning in schools experienced a significant change from conventional learning (face-to-face) to online learning, follow the health protocol physical distancing recommended by the current government. STEM-PjBL online learning through platform was e-learning effectively carried out during the Covid19 pandemic by providing projects to students involving science, technology, engineering and mathematics. STEM-PJBL learning enhances learning outcomes, learners' competencies and learning motivations, creates more meaningful learning, helps students solve problems, and supports future careers. The use of online applications for learning in the form of google classroom and social media becomes the main choice based on the level of ease of use. STEM-PJBL. This STEM-PjBL learning also demonstrates students' scientific abilities including reading, observing, and solving problems in daily life. The improvement of life skills includes personal, social, academic and vocational skills. This integration is more effective than conventional learning in improving learning outcomes in the form of creative thinking skills and science process skills. The constraints of online learning include limited internet services, as well as user infrastructure and infrastructure, some of which have not yet been fulfilled, for example smartphones and laptops, so that further and maximum efforts are needed from all parties.
\end{abstract}

Key words: transformation, project-based learning, STEM, Covid-19

\title{
How to Cite
}

Saputra, Beny, Agus Sujarwanta. 2021. Transformasi Pembelajaran Berbasis Proyek Science, Technology, Engineering and Mathematics di Masa Pandemi Covid-19. Biolova 2(1). 1-8. 


\section{PENDAHULUAN}

Pandemi Covid 19 memberi efek yang luar biasa besar diseluruh sendi kehidupan, tidak terkecuali di dunia pendidikan baik di level dasar hingga perguruan tinggi. Kegiatan pembelajaran bertransformasi dari belajar di sekolah berubah menjadi kegiatan belajar di rumah masing-masing. Hal ini tentu saja membawa konsekuensi baru bagi pendidik dan peserta didik dalam menyiapkan segalanya selama kegiatan pembelajaran. Transformasi pembelajaran di masa pandemi secara daring menjadi pilihan yang tidak mungkin ditolak lagi, sesuai dengan surat edaran Kementerian Pendidikan dan Kebudayaan Direktorat Pendidikan Tinggi No. 1 Tahun 2020 tentang penyelenggaraan pembelajaran jarak jauh yang bertujuan sebagai pencegahan penyebaran Corona Virus Disease (Covid), menggunakan perangkat digital menuntut pendidik dan peserta didik memiliki sikap adaptif terhadap pembelajaran daring yang terintegerasi melalui jaringan internet di rumah masing-masing.

Di samping itu, pembelajaran yang dilakukan secara daring ini dengan menggunakan jaringan internet, tentu saja sejalan dengan pembelajaran di era Revolusi Industri 4.0, peserta didik diharapkan mampu menggunakan perangkat komputer, sensor dan data atau internet of things (IOT) (Herman et. al., 2016), lembaga pendidikan termasuk sekolah pun dituntut mampu melahirkan generasi yang berkualitas yang mampu beradaptasi dengan berbagai tantangan (Gardiner et. al.,2017), sehingga penekanan pendidikan di Indonesia saat ini dalam ranah kognitif dengan menciptakan peserta didik yang mampu berpikir kritis, bertindak kreatif, produktif, mandiri, kolaboratif, dan komunikatif (Kemendikbud, 2016).

Pentingnya STEM dalam mambangun dan menjembatani pembelajaran saat ini bahwa keterampilan sains, keterampilan teknologi dan teknik, serta keterampilan manajemen, pengetahuan dan sumber daya sangat diperlukan (Kuenzi, 2008; Jang, 2016). STEM merupakan singkatan dari Science, Technology, Engineering and Mathematic, adalah sebuah pendekatan pembelajaran interdisipliner antara sains, teknologi, teknik dan matematika, didalamnya terdapat kesesuaian antara antara ke empat aspek tersebut terhadap dunia nyata dan pembelajaran berbasis masalah, mampu menciptakan pembelajaran yang aktif dan kohesif sehingga perserta didik mampu menyatukan konsep yang abstrak dari setiap aspek (Torlakson, 2014). Keempat aspek STEM mampu menciptakan sistem pembelajaran aktif kohesif yang dibutuhkan dalam waktu yang bersamaan untuk menyelesaikan masalah (LaboyRush, 2010).

Pembelajaran multidisiplin ilmu STEM ini secara alami melibatkan banyak keterampilan yang berbeda-beda, diantaranya membaca, menulis, matematis dan membangun konsep pengetahuan (Capraro, Carparo dan Morgan, 2013). Implementasi ini sejalan dengan pembelajaran berbasis proyek (PjBL) yang mampu meningkatkan hasil belajar kognitif (Baran dan Maskan, 2010), membentuk sikap (Kilinic, 2010; Tseng et. al., 2013), keterampilan proses ilmiah (Özer dan Özkan, 2012), dan pembelajaran yang efektif (Cook, Buck dan Rogers, 2012; Movahedzadeh, et al., 2012).

Integrasi STEM-PjBL menurut Tseng, dkk (2013) dapat meningkatkan motivasi belajar peserta didik, menciptakan pembelajaran yang lebih bermakna, membantu peserta didik dalam memecahkan masalah, dan mendukung karir di masa depan. Pembelajaran STEM$\mathrm{PjBL}$ ini juga memperlihatkan kemampuan sains peserta didik meliputi membaca, mengamati, dan memecahkan masalah dalam kehidupan sehari-hari (Mayasari, Kadorahman dan Rusdiana, 2014). Melalui pembelajaran STEM-PjBL 
ini peserta didik diharapkan memiliki hardskill dan soft skill serta kemampuan kognitif dan kemampuan berpikir kritis berkembang sesuai kebutuhan kompetensi saat ini. Pembelajaran STEM-PjBL tertuang pada Gambar 1.

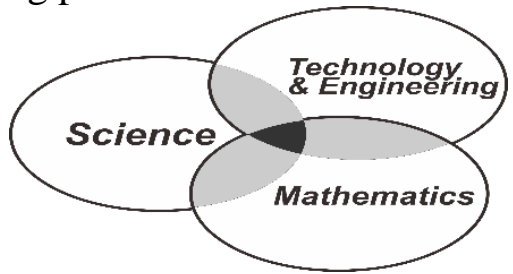

Gambar 1 Pendekatan Pendidikan STEM

Berdasarkan pemaparan di atas, masalah dalam penelitian ini adalah (1) apakah model pembelajaran STEM-PjBL efektif diterapkan kepada peserta didik selama masa pandemic Covid-19 2) Apakah model pembelajaran STEM-PjBL mampu meningkatkan kompetensi peserta didik selama masa pandemi Covid 19.

\section{METODE PENELITIAN}

Penelitian ini termasuk dalam studi literatur. Jenis data yang digunakan adalah kumpulan data sekunder berupa hasilhasil penelitian dari berbagai artikel, dokumen pembelajaran, sumber pustaka, dan pembelajaran online berbasis proyek. Data yang telah didapatkan kemudian dikumpulkan, diramu, dikaji, dan dianalisis serta disimpulkan sehingga mendapatkan rekomendasi mengenai studi literatur.

\section{HASIL DAN PEMBAHASAN Transformasi Pembelajaran di Masa Pandemi COVID-19}

Pendidikan di Indonesia, sejak dikeluarkannya surat keterangan Kemendikbud Tahun 2020 ini telah merubah pembelajaran mulai dari tingkatan sekolah dasar, menengah bahkan sampai tingkat perguruan tinggi. Transformasi pembelajaran ini memaksa instansi pendidikan, pendidik (guru dan dosen) untuk merancang dan mengaplikasikan proses pembelajaran yang tepat pada masa pandemi Covid 19.

Pemerintah telah mengeluarkan regulasi baru yaitu physical distancing (menjaga jarak) untuk mencegah penyebaran Covid 19 agar tidak menyebar luas, membuat proses pembelajaran ditransformasikan menjadi belajar di rumah, dilakukan secara daring (online).

\section{Pembelajaran Daring menggunakan $E$ - learning}

Dari hasil penelitian sebelumnya menunjukkan perbandingan antara pembelajaran konvensional (tatap muka di sekolah) dan pembelajaran daring (online) memberi hasil belajar yang berbeda, pembelajaran daring mempunyai kelebihan dan memberi pengaruh lebih tinggi daripada pembelajaran menggunakan media LKS terhadap hasil belajar (Santoso, 2009).

Pembelajaran daring memiliki tantangan tersendiri yang kompleks, ketersediaan layanan internet masingmasing daerah menjadi faktor penting yang harus diperhatikan. Selain itu sarana dan prasarana lain berupa ketersediaan gadget/smartphone android, juga menjadi masalah yang tidak bisa diabaikan begitu saja menengok tidak semua pendidik dan peserta didik memiliki perangkat tersebut dan faktor gagap teknologi, serta ketersediaan biaya untuk pembelian layanan internet juga menjadi alasan terhambatnya pembelajaran daring (Gunawan dan Fathoroni, 2020).

Tidak sedikit aplikasi pembelajaran daring yang dikembangkan agar bisa diaplikasikan pada pembelajaran jarak jauh. Pendidik dan peserta didik dapat menggunakan layanan aplikasi yang berbayar maupun bebas pakai (gratis). Salah satu aplikasi gratis yang sudah terpasang di smartphone android adalah google classroom. Aplikasi ini memberi kemudahan bagi pengguna maupun tutor, yakni pendidik, dengan membuka kelas dan mengundang peserta didik untuk 
dapat masuk di dalam kelas tersebut. Pemberian materi dan tugas dapat diberikan langsung kepada peserta didik secara daring. Pendidik dapat memberikan penilaian terhadap tugas yang diberikan dengan cara peserta didik mengunggah tugas tersebut sehingga pengumpulan tugas bisa dilakukan secara rapih dan terarsip dengan baik. Penggunaan aplikasi ini memungkinkan pembelajaran antara pendidik dan peserta didik tanpa harus melalui proses tatap muka di kelas melalui pemberian materi pembelajaran berupa slideshow powerpoint, video pembelajaran dan buku elektronik ( $e$ book). Pendidik juga dapat memberikan tugas baik mandiri maupun kelompok yang sekaligus dapat diberi penilaian. Selama pembelajaran daring, pendidik dan peserta didik memungkinkan untuk berinteraksi melalui forum diskusi yang disediakan oleh aplikasi google classroom terkait dengan materi pembelajaran maupun hal-hal yang belum dipahami peserta didik secara interaktif.

Fasilitas lain yang bisa didapatkan pengguna google classroom ini berupa video conference dengan menggunakan google meet yang sudah otomatis terpasang sebagai aplikasi bawaan google. Penggunaan aplikasi google classroom ini cukup efektif dilakukan dalam pembelajaran daring, dengan tingkat kecenderungan sebesar 77,27\% (Sabran dan Sabara, 2018), memberikan pengaruh yang signifikan dalam pembelajaran berupa kemudahan, kemanfaatan dan efektivitas (Sari, 2019). Selain google classroom, pendidik dan peserta didik juga dapat menggunakan aplikasi atau situs pembelajaran daring secara gratis di Indonesia antara lain, rumah belajar, Ruang guru, Zenius, google for education, kelas pintar, quipper school yang bisa diakses kapanpun di manapun. Sebagian besar pendidik dan peserta didik juga menggunakan media sosial dalam pelaksanaan pembelajaran, meliputi, facebook dan whatsapp. Kedua aplikasi ini sangat familiar bagi pemegang smarphone, penggunaan yang mudah dan sederhana memungkinkan semua kalangan dapat mengoperasikannya, selain itu, fasilitas berupa unggah foto, file, dan data juga tersedia dalam aplikasi ini sehingga memudahkan pendidik dan peserta didik untuk saling memberi tugas dan mengumpulkan tugas.

Penerapan pembelajaran secara daring juga harus memperhatikan hal-hal yang penting agar tujuan dari pembelajaran tersebut dapat tercapai, sebagaimana Setyosari (2007) menjabarkan lima hal penting tersebut antara lain, 1) tingkat relevansi materi terhadap ketercapaian tujuan khusus pembelajaran, 2) penggunaan metode yang dapat membantu peserta didik, 3) penggunaan media untuk menyajikan isi dan metode baik gambar maupun tulisan, 4) mengembangkan dan membangun pengetahuan dan keterampilan pendidik.

\section{Pembelajaran berbasis proyek $(\mathrm{PjBL})-$ STEM}

Pembelajaran berbasis proyek merupakan salah satu pendekatan pembelajaran yang dapat meningkatkan kompetensi peserta didik. Pendekatan ini dapat memberikan interaksi yang aktif dan efektif peserta didik dengan memanfaatkan proses penyelidikan, membangun dan mengembangkan produk yang aplikatif dan bermanfaat dalam kehidupan sehari-hari. Pembelajaran berbasis proyek membantu peserta didik dalam mengembangkan teknologi, sosial, dan inti dari kurikulum (Sahin, 2013), meningkatkan kecakapan hidup peserta didik (Arizona, dkk, 2018). Peningkatan kecakapan hidup ini meliputi kecakapan personal, sosial, akademik dan vokasional. Pembelajaran PjBL ini lebih efektif dibandingkan dengan pembelajaran konvensional dalam meningkatkan hasil belajar berupa kemampuan berpikir kreatif dan keterampilan proses sains (Chasanah, Khoiri dan Nuroso, 2014). 
Pembelajaran berbasis proyek ini dapat dintegerasikan dengan sains, teknologi, teknik, dan matematika (STEM) di mana antara sains dan teknologi atau pengetahuan tidak dapat dipisahkan dalam pembelajaran sains. Di dalam STEM, matematika digunakan untuk alat analisis data, sedangkan pengaplikasiannya membutuhkan teknologi dan teknik. Pendekatan STEM ini dapat memberikan pembelajaran yang bermakna bagi peserta didik melalui integrasi sistematis antara pengetahuan, konsep, dan keterampilan, meningkatkan keterampilan pemecahan masalah peserta didik, inovator, independen, pemikir lokal dan literasi teknologi.

Pembelajaran STEM-PjBL perlu menekankan beberapa aspek dalam pembelajaran (National Research Council, 2011), seperti: (1) mengajukan pertanyaan (sains) dan mendefinisikan masalah (teknik), 2) meningkatkan dan menggunakan model, 3) merencanakan dan melakukan penyelidikan, 4) menganalisis dan menafsirkan data (matematika), 5) menggunakan matematika dan teknologi informasi, 6) membangun penjelasan (sains) dan merangcang solusi (teknik), 7) terlibat dalam argumen berdasarkan bukti, 8) memperoleh, mengevaluasi, dan mengkomunikasikan informasi.

\section{Transformasi pembelajaran daring berbasis proyek (PjBL)-STEM di masa pandemik Covid-19}

Pembelajaran secara daring menggunakan platform e-learning dalam pembelajaran berbasis proyek dinilai secara signifikan efektif dalam pencapaian sikap spiritual, sikap sosial, proyek, produk dan ketuntasaan belajar peserta didik (Noor et. a., 2017). Berdasarkan hasil penelitian yang telah dipaparkan, pembelajaran STEM-PjBL secara daring ini menjadi salah satu solusi di tengah pandemik Covid-19 untuk meningkatkan dan mengoptimalkan pembelajaran, yang dilakukan di rumah masing-masing dalam rangka physical distancing, mencegah dan memutus mata rantai penyebaran covid-19. Pembelajaran bermakna dapat diraih oleh peserta didik dengan memadukan pembelajaran STEM$\mathrm{PjBL}$ secara daring, sehingga pengetahuan dan ilmu yang didapatkan peserta didik dapat menjadi bekal dan pemecah masalah dalam kehidupan sehari-hari.

\section{KESIMPULAN}

Pembelajaran di masa pandemi covid-19 harus bertransformasi menjadi pembelajaran daring, peserta didik belajar dari rumah menggunakan perangkat smartphone dengan tujuan mengikuti protokol kesehatan yang berlaku demi mencegah penyebaran Covid-19 melalui physical distancing, sejalan dengan pembelajaran di era Revolusi Industri 4.0, yakni pembelajaran digital. Transformasi Pembelajaran STEM-PjBL efektif dilakukan oleh pendidik dan peserta didik di masa pandemic Covid-19 secara daring dengan memberikan proyek kepada peserta didik yang melibatkan sains, teknologi, teknik dan matematika. Pembelajaran STEM-PjBL meningkatkan kompetensi peserta didik yang didalamnya melibatkan banyak keterampilan sains, teknologi, teknik, dan matematika, memfasilitasi peserta didik dalam mempelajari konsep secara mendalam dan meningkatkan hasil belajar. Kendala dari pembelajaran daring ini meliputi layanan internet yang terbatas, serta sarana dan prasarana pengguna sebagian belum terpenuhi, misalnya smartphone dan laptop, sehingga perlu upaya lebih lanjut dan maksimal dari semua pihak.

\section{DAFTAR LITERATUR}

Arizona, K., Abidin, Z., dan Rumansyah, R. 2020. Pembelajaran Online Berbasis Proyek Salah Satu Solusi Kegiatan Belajar Mengajar di Tengah Pandemi Covid-19. Jurnal 
Ilmiah Profesi pendidikan, 5(1), 64-70.

Baran, M. dan Maskan, A. 2010. The Effect of Project-based learning on pre-service physics teachers' electrostatic achievements. Cypriot Journal of Educational Sciences, 5: 243-257.

Capraro, R.M., Capraro, M.M., dan Morgan, J.R. 2013. STEM projectbased learning: An integrated science, technology, engineering, and mathematics (STEM) approach second ed). Rotterdam: Sense

Chasanah, ARU, Khoiri, N. dan Nuroso, H. 2016. Efektivitas Model Project Based Learning terhadap Keterampilan Proses Sains dan Kemampuan Berpikir Kreatif Peserta didik pada Pokok Bahasan Kalor Kelas X SMAN 1 Wonosegoro Tahun Pelajaran 2014/2015. Jurnal Penelitian Pembelajaran Fisika. 7 (1), 19-24.

Cook, K., Buck, G., dan Rogers, M.P. 2012. Preparing Biology Teachers to Teach Evolution in a ProjectBased Approach. Winter, 21(2): 18-30.

Gardiner, M.O., S.I. Rahayu, M.A. Abdullah, S. Effendi, Y. Darma, T. Dartanto, dan C.D. Aruan. 2017. Era Disrupsi: peluang dan tantangan pendidikan tinggi indonesia. Jakarta: Akademi Ilmu Pengetahuan Indonesia.

Gunawan, Suranti, NMY. dan Fathoroni 2020. Variations of Models and Learning Platforms for Prospective Teachers During the COVID-19 Pandemic Period. Indonesian Journal of Teacher Education. 1 (2), 61-70
Hermann, M., Pentek, T. dan Otto, B. 2016. Design Principles for Industrie 4.0 Scenarios. Presented at the 49th Hawaiian International Conference on Systems Science.

Jang, H. 2016. Identifying $21^{\text {st }}$ century STEM competencies using workplace data. Journal of Science Education and Technology, 25(2), 284-301.

Kemdikbud. 2016. Materi pelatihan guru implementasi kurikulum 2013 tahun ajaran 2014/2015: Mata pelajaran IPA SMP/MTs. Jakarta: Kementerian Pendidikan dan Kebudayaan.

Kılınç, A. 2010. Can Project-Based Learning Close the Gap? Turkish Student Teachers and Proenvironmental Behaviours. International Journal of Environmental dan Science Education, 5: 495-509.

Kuenzi, JJ. 2008. Science, technology, engineering, and mathematics (STEM) education: Background, federal policy, and legislative action.

Laboy-Rush, D. 2010. Integrated STEM education through project-based learning.www.learning.com/stem/ whitepaper/integrated-STEMthrough Project- based Learning.

Mayasari, T., Kadorahman, A., dan Rusdiana, D. 2014. Pengaruh pembelajaran terintegrasi science, technology, engineering, and mathemathics (STEM) pada hasil belajar peserta didik: Studi meta analisis, Prosiding Semnas Pensa VI "Peran Literasi Sains" 20 Desember 214, Surabaya. 
Movahedzadeh, F., Patwell, R., Rieker, J. E., dan Gonzalez, T. 2012. Projectbased learning to promote effective learning in biotechnology courses. Education Research International, 2012, 1-8.

National Research Council. 2011. A Framework for K-12 Science Education: Practices, Crosscutting Concepts, and Core Ideas. Washington DC: The National Academies Press

Sabran dan Sabara, E. 2018. Keefektifan Google classroom sebagai Media Pembelajaran. Prosiding Seminar Nasional LembagaPenelitian Universitas Negeri Makassar "Diseminasi Hasil Penelitian Melalui Optimalisasi Sinta dan Hak Kekayaan Intelektual", 122125

Sahin, A. 2013. STEM Project-Based Learning. Boston, USA: Sense Publishers

Santoso, E. 2009. Pengaruh Pembelajaran Online Terhadap Prestasi Belajar Kimia Ditinjau Dari Kemampuan Awal Peserta didik. Tesis. Program Pasca Sarjana Universitas Sebelas Maret Surakarta.

Sari, IN. 2019. Pengaruh Penggunaan Google classroom terhadap Efektivitas Pembelajaran Mahapeserta didik Universitas Islam Indonesia. Skripsi. Fakultas Ekonomi Universitas Islam Indonesia Yogyakarta.

Setyosari, P. 2007. Pembelajaran Sistem Online: Tantangan dan Rangsangan. Majalah Ilmiah Pembelajaran 2, 1-10.
Torlakson, T. 2014. INNOVATE: A blueprint for science, technology, engineering, and mathematics in California public education. Dublin, CA: Californians Dedicated to Education Foundation

Tseng, K.H., Chang, C.C., Lou, S.J., dan Chen, W.P. 2013. Attitudes towards science, technol- ogy, engineering and mathematics (STEM) in a project based learning (PjBL) environment. International Journal Technology and Design Edu-cation, 23: 87-102.

Özer, D. Z. dan Özkan, M. 2012. The Effect of the project based learning on the science process skills of the prospective teachers of science. Journal of Turkish Science Education, 9 (3): 131-136. 